\title{
Antimicrobial screening of some medicinal plants from Mato Grosso Cerrado
}

\author{
Iberê F. Silva Junior, ${ }^{1,4}$ Valdir Cechinel Filho, ${ }^{2}$ Susana A. Zacchino, ${ }^{3}$ Joaquim Corsino da S. \\ Lima, ${ }^{1}$ Domingos Tabajara de O. Martins $*, 1$ \\ ${ }^{1}$ Departamento de Ciências Básicas em Saúde, Universidade Federal de Mato Grosso, 78060-900 \\ Cuiabá-MT, Brazil, \\ ${ }^{2}$ Núcleo de Investigações Químico-Farmacêuticas, Universidade do Vale do Itajaí, 88302-202 Itajai-SC, Brazil, \\ ${ }^{3}$ Farmacognosia, Facultad de Ciencias Bioquímicas y Farmacéuticas, Universidad Nacional del Rosario, \\ Suipacha, 531 Rosario, Argentina, \\ ${ }^{4}$ Faculdade de Farmácia, Universidade de Cuiabá, 78015-480 Cuiabá-MT, Brazil
}

\begin{abstract}
RESUMO: "Triagem antimicrobiana de algumas plantas medicinais do Cerrado de Mato Grosso". Os extratos em hexano, diclorometano, acetato de etila e etanol das entrecascas de Bowdichia virgilioides, Calophyllum brasiliense, Cariniana rubra, Lafoensia pacari e Stryphnodendron obovatum, do rizoma de Simaba ferruginea e do látex de Croton urucurana foram triados contra um painel de bactérias e fungos usando o método de microdiluição em caldo. O látex de Croton urucurana foi o material derivado de planta com maior atividade antimicrobiana. Os extratos em acetato de etila e hexano da entrecasca de Calophyllum brasiliense destacaram-se por suas seletivas atividades antibacterianas. Os extratos polares da entrecasca de Lafoensia pacari notabilizaram-se por suas potentes e seletivas atividades contra leveduras e os extratos polares e não-polares de Bowdichia virgilioides por suas atividades antifúngicas contra hialo-hifomicetos e dermatófitos. Este é o primeiro relato mostrando atividades antifúngicas para os extratos de Cariniana rubra e Simaba ferruginea. Esse trabalho demonstrou a atividade antimicrobiana de plantas medicinais do Cerrado de Mato Grosso em ensaios in vitro e indica que elas podem ser potenciais candidatas para o desenvolvimento de novas estratégias no tratamento de infecções bacterianas e fúngicas.
\end{abstract}

Unitermos: Plantas medicinais, Cerrado de Mato Grosso, triagem antimicrobiana, ensaio de microdiluição em caldo.

\begin{abstract}
Hexane, dichloromethane, ethyl acetate and ethanol extracts from stem barks of Bowdichia virgilioides, Calophyllum brasiliense, Cariniana rubra, Lafoensia pacari, and Stryphnodendron obovatum and rhizome of Simaba ferruginea and Dragon's blood red sap from Croton urucurana were screened against a panel of bacteria and fungi using the micro-broth dilution method. Dragon's blood from Croton urucurana was the most effective antimicrobial plant material. Ethyl acetate and hexane extracts of Calophyllum brasiliense stem bark deserved distinction by their selective antibacterial activity. Lafoensia pacari stem bark polar extracts distinguished by their potent and selective anti-yeast activity and Bowdichia virgilioides polar and non-polar extracts by their antifungal activity towards hyalohypho-mycetes and dermatophytes. This is the first report showing antifungal activity for polar extracts of Cariniana rubra and Simaba ferruginea. This study has demonstrated antimicrobial activity of Mato Grosso Cerrado ethnomedicinal plants in in vitro assays and has indicated that they can be effective potential candidates for the development of new strategies to treat fungal and bacterial infections.
\end{abstract}

Keywords: Ethnomedicinal plants, Mato Grosso Cerrado, antimicrobial screening, micro-broth dilution assay.

\section{INTRODUCTION}

The most extensive woodland/savanna region in South America, the "Cerrado" (Figure 1) is also the only hotspot that consists largely of savanna, woodland/ savanna and dry forest ecosystems (Silva and Bates, 2002). The region that covers more than 2 million square kilometers of Brazilian island is home to an estimated 10,000 plants species, of which about those 4,400 are endemic (Klink and Machado, 2005).

Antimicrobial resistance is a natural biological phenomenon. After a flurry of discoveries between 1930 and 1970, the past 30 years have witnessed fewer discoveries in the fight against infectious killers. Nowadays, the cache of antimicrobial weapons targeting infections disease has swollen to an impressive arsenal of more than 150 compounds. However, the cost has been huge (WHO, 2000). 
Since the advent of antibiotics in the 1950s, the use of plant derivatives as antimicrobials has been virtually absent. The use of plant extracts, as well as other alternative forms of medical treatments, is enjoying great popularity in the late 1990s. The reasons for this renaissance include a reduction in the new antimicrobial drugs in the pharmaceutical pipeline, an increase in antimicrobial resistance, and the need of treatments for new emerging pathogens (Mahady, 2005).

In an effort to discover new lead compounds, scientists from different areas are investigating new plants aiming the detection of secondary metabolites with relevant antimicrobial usefulness that can be further synthesized for improving their activity. (Cowan, 1999; Serafin et al., 2007; Silva et al., 2007; Coutinho et al., 2008).

The aim of this work was to carry out an antimicrobial screening of twenty-four extracts obtained from stem bark of six plant species and one blood redsap of one medicinal plant occurring in Mato Grosso Cerrado, Brazil.

\section{MATERIAL AND METHODS}

\section{Plant collection and extract preparation}

All plants were collected, during February, 2004 in Cerrado regions from the State of Mato Grosso, Brazil, and its botanical identity was confirmed by MSc. Harri Lorenzi of the Plantarum Institute, in São Paulo, Brazil. Voucher specimens were deposited at Central Herbarium of Universidade Federal do Mato Grosso (Table 1).

Each part collected was dried at $40{ }^{\circ} \mathrm{C}$ for 3 days to constant weight and afterwards triturated. The dried powdered was macerated successively with hexane, dichloromethane, ethyl acetate and ethanol 75\% (3:1 $\mathrm{w} / \mathrm{v}$ ) at room temperature for 7 days. Each macerate was separated by filtration and concentrated under reduced pressure. The dragon's blood from Croton urucurana was tested pure in nature.

\section{Microbial strains}

Antimicrobial activity was carried out using microorganisms proceeding from the American Type Culture Collection (ATCC, Rockville, MD, USA) or clinical isolates provided by the Institute Adolfo Lutz, São Paulo, Brazil (IAL): Candida albicans ATCC 10231, Candida krusei ATCC 6258, Candida tropicalis ATCC 750, Candida parapsilosis ATCC 22019, Candida glabrata ATCC 90030, Saccharomyces cerevisiae ATCC 9763, Cryptococcus neoformans ATCC 32264, Aspergillus niger ATCC 16404, Aspergillus flavus IAL 552, Aspergillus fumigatus IAL 640, Microsporum canis IAL 578, Microsporum gypseum IAL 579, Trichophyton rubrum IAL 612, Trichophyton mentagrophytes IAL 581, Trichophyton tonsurans IAL 592 and Epidermophyton floccosum IAL 577. The bacterial strains used were Staphylococcus aureus ATCC 25923, Staphylococcus epidermidis ATCC 12228, Streptococcus pyogenes ATCC 19615, Enterococcus faecalis ATCC 29212, Salmonella typhimurium ATCC 14028, Pseudomonas aeruginosa ATCC 27853, Shiguella flexneri ATCC 12022, Klebsiella pneumoniae ATCC 13883, Escherichia coli ATCC 25922, Enterobacter aerogenes ATCC 13048 or clinical isolates, Streptococcus agalactiae, Proteus mirabilis, Citrobacter koseri and Serratia marcescens. The strains were maintained on slopes of Sabouraud-dextrose agar (Oxoid) for fungi and TSB agar (Oxoid) for bacteria, and subcultured every 15 days to prevent pleomorphic transformations.

\section{Antimicrobial activity - Micro-broth dilution test}

Minimal Inhibitory Concentrations (MICs) were determined using microplates of 96 wells according guidelines by CLSI M27A2 and M38A (CLSI, 2002 and 2003). Stock solutions of extract and fractions in DMSO (Sigma) were diluted to give serial twofold dilutions which were added to each medium, resulting in concentrations ranging from 1000 to $8 \mu \mathrm{g} / \mathrm{mL}$ for extracts and dragon's blood. Inocula of $100 \mu \mathrm{L}$ (final concentration $10^{4} \mathrm{CFU} / \mathrm{mL}$ ) were added to MüellerHinton broth (Micro Med) supplemented with $2 \%$ of glucose for fungi and bacterial. Amphotericin B (Sigma), chloramphenicol (Sigma) and terbinafine (Novartis) were used as positive controls. Plates were incubated for 24, 48 or $72 \mathrm{~h}$ at $30^{\circ} \mathrm{C}$ (according to the control growth) up to 15 days for dermatophyte strains MIC is expressed as the lowest concentration which inhibited growth judged by lack of turbidity in the tube. All antimicrobial assays were tested in duplicate.

\section{RESULTS AND DISCUSSION}

Seven medicinal plants (Bowdichia virgilioides, Calophyllum brasiliense, Lafoensia pacari, Simaba ferruginea, Cariniana rubra, Stryphnodendron obovatum and Croton urucurana) were selected for assay of antibacterial and antifungal activity. From the stem bark of these plants, 24 extracts were prepared by sequential maceration with organic solvents and screened to inhibit the growth of bacteria and fungi using micro-broth dilution assay. Dragon's blood from Croton urucurana was assayed pure in nature. The seven ethnomedicinal plants screened occur in Mato Grosso Cerrado from Brazil (Guarim-Neto and Morais, 2003). Plant materials with MIC values $\leq 1000 \mu \mathrm{g} / \mathrm{mL}$ were considered active.

The broth dilution method, one of the most commonly used screens to determine antimicrobial susceptibility, is a simple procedure for testing a small number of isolates, even a single isolate (Tanaguchi and Kubo, 1993). Additionally, it has also the advantage that the same tubes can be taken for Minimum Bactericidal 
Table 1. Medicinal plants collected.

\begin{tabular}{cclll}
\hline & $\begin{array}{c}\text { Voucher } \\
\text { specimen }\end{array}$ & Plant species & Family & Part collected \\
\hline 1 & 35591 & Bowdichia virgilioides H.B. \& K. & Leguminosae-Papilionoideae & Stem bark \\
2 & 35583 & Calophyllum brasiliense Camb. & Clusiaceae & Stem bark \\
3 & 35576 & Cariniana rubra Miers. & Lecythidaceae & Stem bark \\
4 & 35011 & Croton urucurana Baill. & Euphorbiaceae & Blood-red sap \\
5 & 35577 & Lafoensia pacari St. Hil & Lythraceae & Stem bark \\
6 & 35570 & Simaba ferruginea A. St. Hil & Simaroubaceae & Stem bark \\
7 & 35584 & Stryphnodendron obovatum Benth. & Leguminosae-Minosoideae & Stem bark \\
\hline
\end{tabular}

Concentration (Lalitha, doc): According to Hadacek and Greger (2000) this method has higher sensibility to antimicrobial agents than the agar diffusion assay because it permits direct contact between drugs, medium and microorganisms, whose are incubated under continuous shaking.

Results of broth dilution assays (Tables 2 and 3 ) showed that only 11 out of 24 plant extracts and the dragon's blood showed antimicrobial activity. The hexane and ethyl acetate stem bark extracts of Calophyllum brasiliense showed selective activity for gram-positive bacteria Staphylococcus aureus, Staphylococcus epidermidis and Streptococcus agalactiae with MIC values of $1000 \mu \mathrm{g} / \mathrm{mL}$, but had no action against gramnegative bacteria (MICs $>1000 \mu \mathrm{g} / \mathrm{mL}$ ). Pretto et al. (2004) demonstrated that methanol extract and polar and non-polar fractions from roots, stem, leaves, flowers and fruits from $C$. brasiliense exhibited selective antimicrobial activity against gram-positive bacteria without effect against gram-negative bacteria. Corttiglia et al. (2004) showed that secondary metabolites obtained from hexane and ethyl acetate stem bark extracts from C. brasiliense displayed antimicrobial activity against gram-positive bacteria. On the other hand, Agripino et al. (2004) did not find antibacterial activity for $C$. brasiliense stem bark extract. Yasunaka et al. (2005) related high activity against Staphylococcus aureus and moderate activity against Escherichia coli for coumarins, xanthones and chromanone acids isolated respectively from leaves and heartwoods of $C$. brasiliense. Our results are in according to these reports that show the presence of selective activity against gram-positive bacteria for $C$. brasiliense stem bark extracts, particularly in non-polar extracts.

The dragon's blood from Croton urucurana was the most active among all the plant material tested, being active against many gram-positive and gram-negative bacteria used in this study, such as Staphylococcus aureus, Staphylococcus epidermidis, Streptococcus agalactiae, Streptococcus pneumoniae, Enterococcus faecalis, Salmonella typhimurium, Shigella flexneri and Proteus mirabilis (MICs $=100$ to $1000 \mu \mathrm{g} / \mathrm{mL}$ ), but had no action against Klebsiella pneumoniae, Escherichia coli, Enterobacter aerogenes, Citrobacter koseri and Serratia marcenses (MICs $>1000 \mu \mathrm{g} / \mathrm{mL}$ ). Peres et al. (1997) showed that the aqueous - ethanol stem bark extract, the hexane and the hexane-dichloromethane fractions from this plant exhibited activity against Staphylococcus aureus and Salmonella typhimurium, being much more active for the first one. To our best knowledge, the scientific literature did not refer any work to antibacterial assay for C. ucururana dragon's blood red sap.

The other 13 plant extracts showed no antibacterial activity (Table 2), in spite of some works support of antibacterial activity against gram-positive bacteria by leaves (Alves et al., 2000) and leaves and stem bark extracts of L. pacari (Lima et al., 2006) and B. virgilioides (Alves et al., 2000) as well as bark extract of $S$. obovatum (Sanches et al, 2005). Such discrepant results may be related with some factors, in particular to environmental factors (seasonality, temperature, collect local, soil nutrients, etc.), which can influence in the production of active principles (Diniz et al., 2007), as well as differences in the methodologies used and differences in the type of extract employed.

Regarding the antifungal activity, all the medicinal plants screened, in general, are more active against fungi than bacteria.

The most effective plant extracts against fungi were Lafoensia pacari and Bowdichia virgilioides. As seen in Table 3, the $d$ ragon's blood from Croton urucurana diaplayed the highest broad-spectrum antifungal activity among the plants tested (MICs $=100-1000 \mu \mathrm{g} / \mathrm{mL}$ ).

In contrast to what occurred in the antibacterial screening, the polar stem bark extracts of Lafoensia pacari were very potent and active against fungi. The ethyl acetate and ethanol extracts showed a selective activity against the yeasts Candida krusei, C. parapsilosis, Saccharomyces cerevisiae and Cryptococcus neoformans (MICs $=100-1000 \mu \mathrm{g} / \mathrm{mL}$ ) This and other extracts from this same plant, did not show any activity against filamentous fungi and dermatophytes (MICs $>1000 \mu \mathrm{g}$ / 


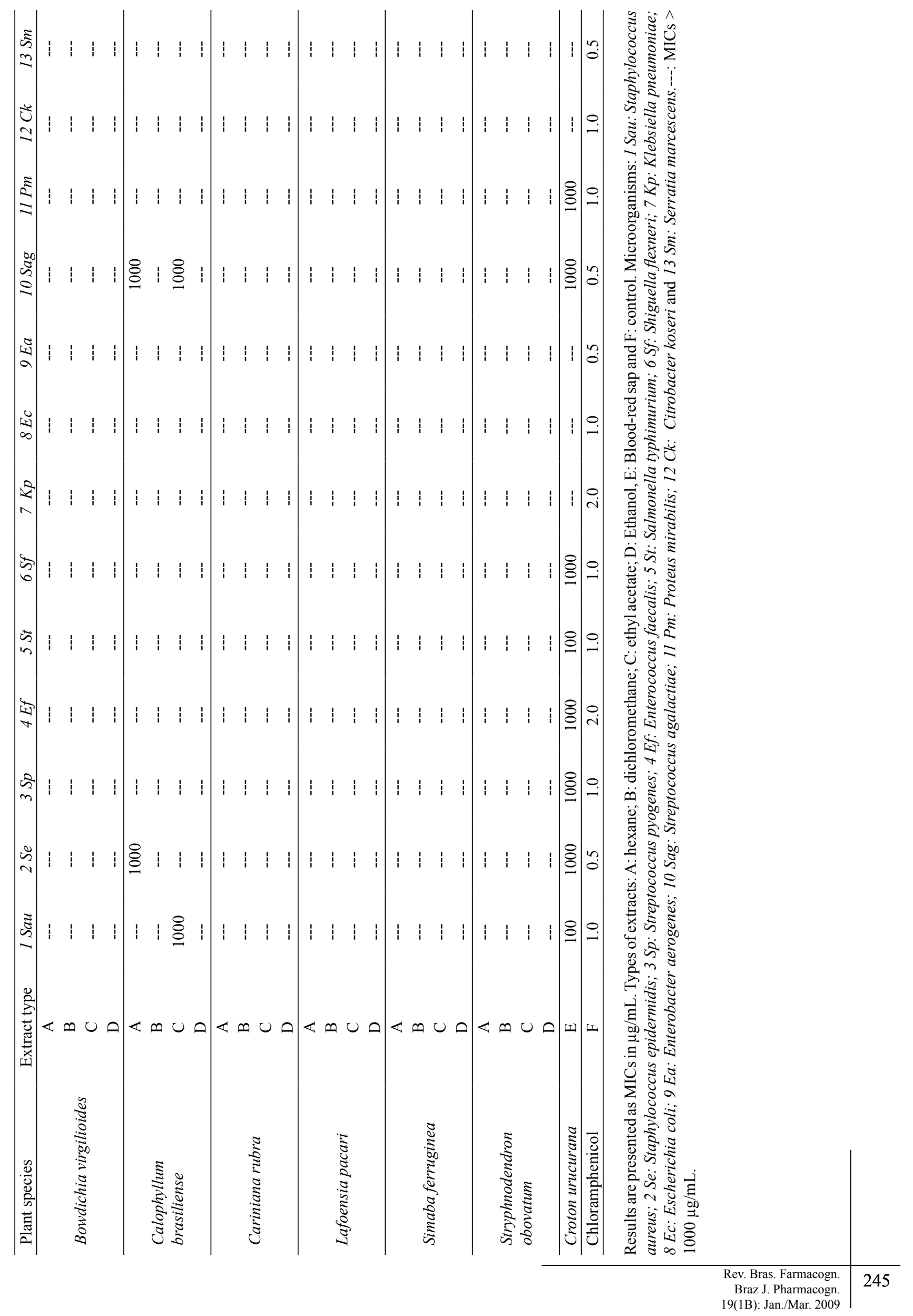




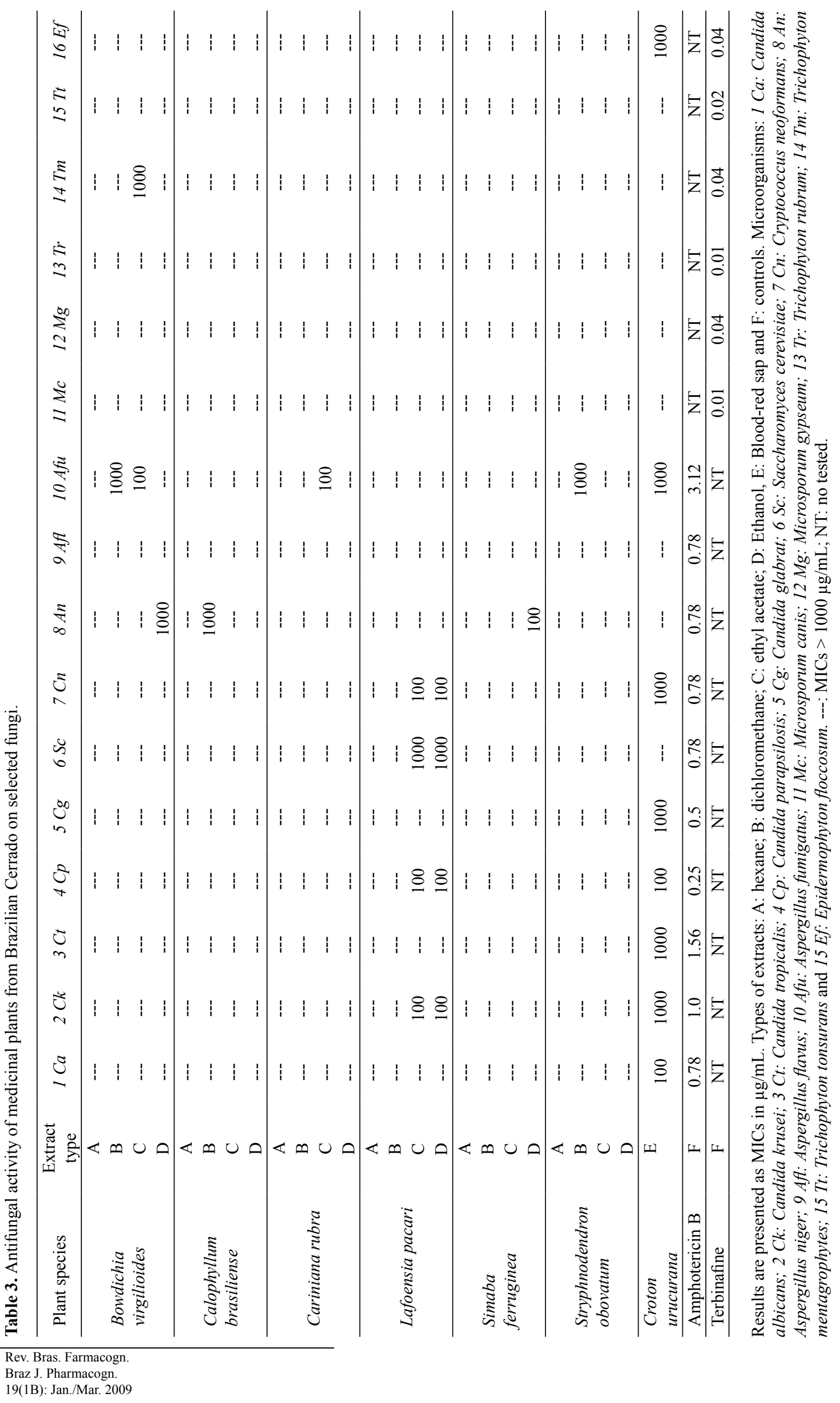




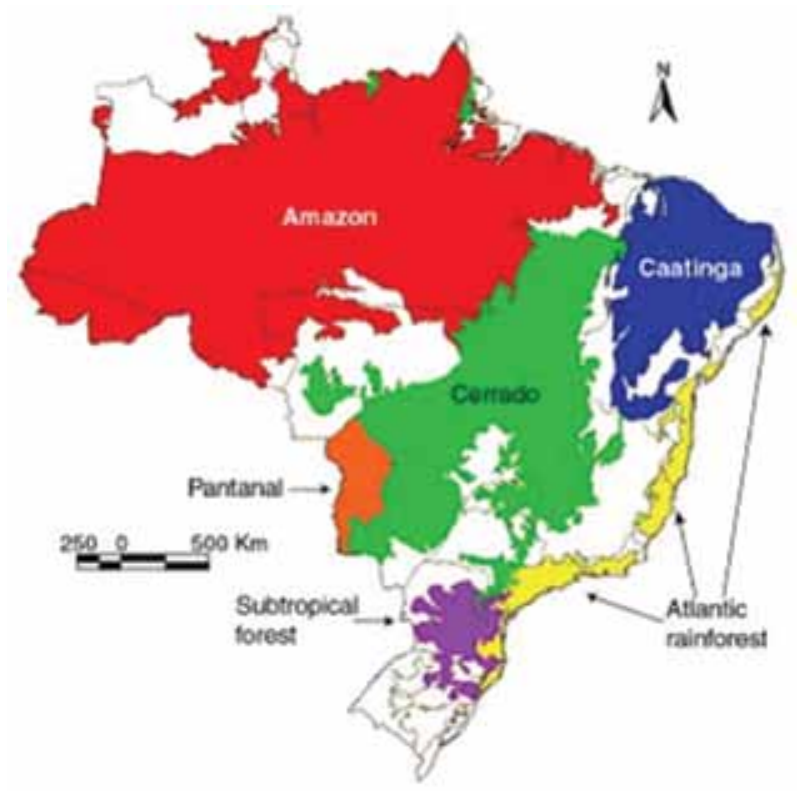

Figure 1. Major biomes of Brazil. The Cerrado spreads across 2,031,990 $\mathrm{km}^{2}$ of the central Brazilian Plateau. (Source: Embrapa, Cenargen, 1999).

$\mathrm{mL}$ ). Alves et al. (2000) showed a discrete antifungal activity against Cladosporium sphaerospermum (a filamentous fungus not tested in our work) for methanol extract of the leaves of $L$. pacari in agar diffusion assay.

The dichloromethane, ethyl acetate and ethanol extracts of the stem bark of Bowdichia virgilioides showed a selective antifungal activity towards hyalohyphomycetes and dermatophytes (MICs $=100-1000 \mu \mathrm{g} / \mathrm{mL}$ ), but had no action against yeasts. Recently, Almeida et al. (2006) demonstrated antifungal activity against Candida albicans, Candida guilliermondii, Candida stellatoidea, Micrococcus luteus and Trichophyton rubrum but using the essential oil of Bowdichia virgilioides leaves.

The only active extract of Calophyllum brasiliense was the dichloromethane one against Aspergillus niger. Agripino et al. (2004) showed intense antifungal activity against Cladosporium cladosporioides (a filamentous fungus not tested in our work) of the ethanol extract of $C$. brasiliense stem bark in agar diffusion test.

In turn, polar extracts of Cariniana rubra (ethyl acetate) and of Simaba ferruginea (ethanol) were active against Aspergillus fumigatus and Aspergillus niger, respectively (MICs $=100-1000 \mu \mathrm{g} / \mathrm{mL}$ ). Our results are the first to demonstrate antimicrobial action for these species.

The dragon's blood from Croton urucurana showed similar antifungal and antibacterial activities, possessing excellent spectrum of action that includes hyalohyphomycetes, yeasts and dermatophytes $(\mathrm{MICs}=$ $100-1000 \mu \mathrm{g} / \mathrm{mL}$ ). Previous studies (Gurgel et al., 2005), reported that dragon's blood from Croton urucurana possesses also antifungal activity against dermatophytes, confirming our results.
Finally, though not found in this study, Sanches et al. (2005) reported antifungal activity against various yeast strains for $S$. obovatum stem bark acetone-water extract and fractions.

\section{CONCLUSION}

This work strongly contributes to the knowledge of the antimicrobial properties of medicinal plants from Brazilian Cerrado by testing the antibacterial and antifungal activities of a series of extracts and blood red-sap of medicinal plants growing in this area of megabiodiversity. Results showed that dragon's blood from Croton urucurana and stem bark extracts of Lafoensia pacari, Calophyllum brasiliense and Bowdichia virgilioides were the most effective plant materials against the panel of microorganisms tested and give a preliminary support to the use of these plants as antimicrobial in the traditional medicine of Cerrado regions of Mato Grosso, Brazil, being an starting point for the future development of new antimicrobial agents.

\section{ACKNOWLEDGEMENTS}

The authors are grateful to CAPES, CNPq, FAPEMAT and CYTED (RIBIOFAR, RT 0284). SZ acknowledges ANPCyT (PICT R 260) and UNR 19/ B133.

\section{REFERENCES}

Agripino DG, Lima MEL, Silva MR, Meda CI, Bolzani VS, Cordeiro I, Young MCM, Moreno PRH 2004. Screening of Brasilian plants for antimicrobial and DNA-damaging activities. I. Atlantic rain Florest Ecological station Juréia-Itatins. Biota Neotrópica 4: $1-15$.

Almeida JRGS, Silva-Filho RN, Nunes XP, Dias CS, Pereira FO, Lima EO 2006. Antimicrobial activity of the essential oil of Bowdichia virgilioides Kunt. Rev Bras Farmacogn 16 (Supl.): 638-641.

Alves TM, Silva AF, Brandao M, Grandi TS, Smania E, Smania Junior A, Zani CL 2000. Biological screening of Brazilian medicinal plants. Mem Inst Oswaldo Cruz 95: 367-373.

CLSI 2002. Clinical and Laboratory Standards Institute, formely NCCLS (National Committee for Clinical Laboratory Standards), Method M27-A2,2 $2^{\text {nd }}$ ed. Wayne Ed.; Vol. 22 (15), pp 1-29. NCCLS, and method M-38A, $2^{\text {nd }}$ ed, Wayne Ed.; Vol. 22 (16), pp 1-27.

CLSI 2003. Clinical and Laboratory Standards Institute, formely NCCLS (National Committee for Clinical Laboratory Standards). Methods for Diluition Antimicrobial Susceptibility Test for Bacteria That Grow Aerobically; Approved Standard - NCCLS document M7-A6; 6 ed. Wayne, Pennsylvania- USA.

Corttiglia F, Dhanapal B, Sticher O, Heilmann J 2004. New chromanone acids with antibacterial activity from Calophyllum brasiliense. J Nat Prod 67: 537-541. 
Coutinho HDM, Costa JGM, Siqueira-Júnior JP, Lima EO 2008. In vitro anti-staphylococcal activity of Hyptis martiusii Benth against methicillin-resistant Staphylococcus aureus-MRSA strains. Rev Bras Farmacogn 18 (Supl.): 670-675.

Cowan MM 1999. Plant products as antimicrobial agents. Clin Microbiol Rev 12: 564-582.

Diniz A, Escuder-Gilabert L, Lopes NP, Gobbo-Neto L, Villanueva-Camañas RM, Sagrado S, MedinaHernández MJ 2007. Permeability profile estimation of flavonoids and other phenolic compounds by biopartitioning micellar capillary chromatography. $J$ Agric Food Chem 55: 8372-8379.

Guarim Neto G, Morais RG 2003. Medicinal plants resources in the Cerrado of Mato Grosso State, Brazil: a review. Acta Bot Bras 17: 561-584.

Gurgel LA, Sidrim JJC, Martins DT, Cechinel Filho V, Rao VS. 2005. In vitro antifungal activity of dragon's blood from Croton urucurana against dermatophytes. $J$ Ethnopharmacol 97: 409-412.

Hadacek F, Greger H 2000. Testing antifungal natural products: methodologies, comparability of resuls and assay choice. Phytochem Anal 11: 137-147.

Klink CA, Machado RB 2005. A Conservação do Cerrado brasileiro. Megadiversidade 1: 147-155.

Lima MRF, Luna JS, Santos AF, Andrade MCC, Sant'Ana AEG, Genet JP, Marquez B, Neuville L, Moreau N 2006. Anti-bacterial activity of some Brazilian medicinal plants. J Ethnopharmacol 105: 137-147

Mahady GB 2005. Medicinal plants for the prevention and treatment of bacterial infections. Curr Pharm Des 11: 2405-2427

Peres MT, Delle Monache F, Cruz AB, Pizzolatti MG, Yunes RA 1997. Chemical composition and antimicrobial activity of Croton urucurana Baillon (Euphorbiaceae). J Ethnopharmacol 56: 223-226.

Pretto JB, Cechinel-Filho V, Noldin VF, Sartori MR, Isaias DE, Cruz AB 2004. Antimicrobial activity of fractions and compounds from Calophyllum brasiliense (Clusiaceae/Guttiferae). Z Naturforsch 59c: 657-662.

Sanches ACC, Lopes GC, Nakamura CV, Dias Filho BP, Mello JCP 2005. Antioxidant and antifungal activities of extracts and condensed tannins from Stryphnodendron obovatum Benth. Rev Bras Cienc Farm 41: 101-107.

Serafin C, Nart V, Malheiros A, Cruz AB, Monache FD, Gette MA, Zacchino S, Cechinel-Filho V 2007. Avaliação do potencial antimicrobiano de Plinia glomerata (Myrtaceae). Rev Bras Farmacogn 17: 578-582.

Silva JMC, Bates JM 2002. Biogeographic patterns and conservation in the South American Cerrado: A tropical savanna hotspot. Bioscience 52: 225-233.

Silva JG, Souza IA, Higino JS, Siqueira-Junior JP, Pereira JV, Pereira MSV 2007. Atividade antimicrobiana do extrato de Anacardium occidentale Linn. em amostras multiresistentes de Staphylococcus aureus. Rev Bras Farmacogn 17: 572-577.

Taniguchi M, Kubo I 1993..Ethnobotanical drug discovery based on medicine men's trials in the African savanna: screening of east African plants for antimicrobial activity II. J Nat Prod 56: 1539-1546.

WHO 2000. World Health Organization on Infectious Diseases 2000. World Health Organization 2000 Publication code: $\mathrm{WHO} / \mathrm{CDS} / 2000.2$
Yasunaka K, Abe F, Nagayama A, Okabe H, Lozada-Pérez L, López-Villafranco E, Muñiz EE, Aguilar A, ReyesChilpa R 2005. Antibacterial activity of crude extracts from Mexican medicinal plants and purified coumarins and xanthones. J Ethnopharmacol 97: 293-299. 